\title{
RAGAM MOTIF FLORA PADA CANDI BUMIAYU SEBAGAI SUMBER PEMBELAJARAN IPS TERPADU (SEJARAH) DI SEKOLAH MENENGAH PERTAMA SRIGUNA PALEMBANG
}

\author{
Oleh: Herianto ${ }^{\star}$, Sukardi ${ }^{\star \star}$, Ahmad Zamhari ${ }^{\star \star \star}$ \\ * Program Studi Pendidikan Sejarah, FKIP Universitas PGRI Palembang \\ ** Program Studi Pendidikan Sejarah, FKIP Universitas PGRI Palembang \\ *** Program Studi Pendidikan Sejarah, FKIP Universitas PGRI Palembang
}

\begin{abstract}
ABSTRAK
Candi Bumiayu merupakan candi peninggalan sejarah masa lampau yang memiliki nilai-nilai sejarah dan budaya yang baik untuk dipelajari dan sekaligus dapat dijadikan sumber pemeblajaran sejarah yang bermanfaat bagi generasi sekarang dan yang akan datang. Masalah pada penelitian ini adalah nilai sejarah apakah pada motif ragam flora candi Bumiayu yang dapat dimanfaatkan sebagai sumber pembelajaran sejarah di sekolah. Tujuan penelitian ini adalah untuk mengetahui nilai sejarah dan budaya keragaman motif flora pada candi Bumiayu yang dapat dimanfaatkan sebagai sumber pembelajaran sejarah di sekolah Menegah Pertama. Manfaat penelitian ini adalah tersedianya sumber pembelajaran sejarahi mata pelajaran IPS Terpadu. Jenis penelitian ini adalah penelitian diskriptif kualitatif. Kesimpulan dalam penelitian ini candi Bumiayu mempunyai ragam motif flora yang beragam. Motif flora itu menggambarkan kehidupan dan kesenian pada masa itu, kerukunan antara umat beragama HinduBudha. Di dalam relief candi Bumiayu terdapat berbagai ragam motif flora atau tumbuhan. Motif itu antara lain adalah bunga teratai, bunga pucuk rebung, motif patra, daun dan lung, motif ikal.
\end{abstract}

Kata Kunci: Motif ragam flora, Candi Bumiayu, Sumber pembelajaran

\section{A. PENDAHULUAN}

Sumatera Selatan merupakan salah satu provinsi yang memiliki kekayaan budaya yang beragam di setiap kabupatennya. Sumatera Selatan merupakan provinsi yang terletak di bagian Selatan pulau Sumatera. Masyarakat Sumatera Selatan sangat menjaga hubungan sosial karena didasari oleh semangat kebangsaan, walaupun dalam kehidupan sehari-hari sangat dipengaruhi adat istiadat. Rumah adat yang terdapat di Sumatera Selatan yaitu rumah limas serta suku yang mendiami wilayah Sumatera Selatan yaitu suku Melayu yang terdiri dari Melayu Palembang, Pasemah, Lematang, Empat lawang, Musi Banyuasin serta Semendo selain suku Melayu terdapat juga suku Jawa Komering serta Sunda. Sehingga dapat membuat kebudayaan Sumatera Selatan menjadi kaya serta unik.

Budaya Sumatera Selatan banyak peninggalan sejarah yaitu candi Bumiayu yang terletak di desa Bumiayu Kabupaten Penukal Abab Lematang llir (PALI). Candi Bumiayu merupakan peninggalan kebudayaan Hindu yang tersingkir oleh kerajaan Sriwijaya yang beragama Budha dan lari kepedalaman pada abad 9 Masehi dan mendirikan bangunan suci keagamaan. Situs Bumiayu yang merupakan salah satu bukti kejayaan agama Hindu di Sumatera Selatan. Di situs Bumiayu terdapat tiga kompleks percandian beserta komponennya. Di kompleks percandian Bumiayu 1 dan 3 banyak arca dewa, hewan dan ukiran tumbuhan atau fauna. Selain candi dan arca candi Bumiayu juga ditemukan keramik asing.Berdasarkan keberadaan temuan-temuan tersebut diduga dahulu merupakan atau memiliki hubungan dagang dan kesenian (Novita, 2011:136137).

Kemudian dalam sejarah masa kerajaan Sriwijaya para penguasa keagamaan dan kesenian banyak didirikan 
percandian pembuatan arca untuk peribadatan.Termasuk di dalamnya kompleks percandian Bumiayu yang mendapat dukungan dengan penguasa Sriwijaya. Kompleks percandian Bumiayu selain mendapat pengaruh agama Budha ada juga yang mendapat pengaruh aliran Tantrayana yang termasuk dalam aliran Budha Mahayana yang mempunyai bahwa seorang penganut dalam mencapai moksa (pelepasan dari keduniawian) dengan menggunakan sihir dan mengucapkan mantra-mantra. Hal ini yang mempengaruhi keunikan dari candi Bumiayu karena dipengaruhi oleh dua atau tiga aliran kepercayaan dalam suatu kompleks percandian. Yang terpenting yang akan dibahas adalah motif flora dalam percandian Bumiayu yang memiliki kesamaan dengan candi yang ada di Jawa (Novita, 2011:136137).

Kegiatan ekskafasi (penggalian tanah yang dilakukan secara sistematis) yang dilakukan di candi Bumiayu 3 terdapat hiasan motif flora yang dipahatkan pada bangunan candi. Motif ini beragam walaupun pada dasarnya hanya sulur atau bonggol yang dipahatkan yaitu pada variasi satu dipahatkan pada antefik berpuncak tiga dengan ukuran $22 \mathrm{~cm}$ lebar $16 \mathrm{~cm}$ dan tebal $14 \mathrm{~cm}$. Penggambaran ragam hias ini didominasi oleh sulur daun yang rangkaian hiasnya ditempatkan secara berurutan dari bawah ke atas yaitu diawali ragam hias bonggol yang menyerupai vas bunga dan kemudian diakhiri hiasan sulur daun bercabang dua yang menjalari sehingga memenuhi bagian atas dan samping badan hiasnya. Sedangkan variasi dua yaitu berpuncak lima dengan ukuran tinggi $17 \mathrm{~cm}$, lebar $16 \mathrm{~cm}$ tebal $7 \mathrm{~cm}$. Ragam hias bonggolnya variasi dua iniberbentuk guci serta hiasan sulur daun yang memenuhi bagian atas dan samping kiri kanan bidang pahatan antefik (Marhaeni, 2000:7).

Ragam hias yang lain adalah bonggol variasi tiga dipahatkan pada sebuah antefik sudut dengan ukuran tinggi $18 \mathrm{~cm}$, lebar
$16,5 \mathrm{~cm}$ dan tebal $20 \mathrm{~cm}$ serta antefik tersebut berpuncak lima. Ragam hiasnya berbentuk bonggol yang di bagian dalamnya diberi hiasan berbentuk lingkaran konsentris yang terputus serta mungkin dimaksudkan sebagai stilasian akar.Dari bonggol keluar tangkai dan kemudian diakhiri dengan hiasan sulur-sulur daun yang memenuhi bagian samping kiri dan kanan bidang pahatan. Serta yang terakhir varian dari bonggol adalah varian empat ditemukan pada antefik berpuncak tiga dengan ukuran tinggi $26 \mathrm{~cm}$, lebar $18 \mathrm{~cm}$ serta tebal 14,5 $\mathrm{cm}$ antefik ini utuh. Ragam hias variasi empat berbentuk bonggol yang menyerupai vas bunga dengan ukuran lingkaran.Dari bagian atas bonggol mencuat tangkai dan sulur daun.Dari bagian atas bonggol mencuat tangkai dan sulur daun yang memenuhi tepi bagian antefik.Pengamatan tekhnik pemahatan menunjukan ragam hias bonggol dengan empat variasinya yang dipahatkan pada antefik tersebut dalam kategori yang rata-rata kedalamannya pada 2-4 cm penggambaran ragam hiasnya terkesan kaku.Penggarapan permukaannya pun kasar (Marhaeni, 2000:7-8 cm).

Selain bentuk bonggol ada juga variasi dari bentuk sulur yang dapat dibedakan menjadi beberapa jenis varian. Variasi satu berhias sulur dengan tinggi $16 \mathrm{~cm}$, lebar 10 $\mathrm{cm}$ dan tebal $20 \mathrm{~cm}$ antefik tersebut berpuncak lima. Ragam hiasnya berbentuk sulur daun yang memenuhi tepian bidang antefik.Di bagian tengah bidang pahatnya terdapat hiasan berbentuk stilasian figur manusia berdiri kangkang. Ragam hias itu dipahatkan pada kedalaman sekitar $2-3 \mathrm{~cm}$. Variasi dua berukuran tinggi $31 \mathrm{~cm}$, lebar 25 $\mathrm{cm}$ dan tebal $9 \mathrm{~cm}$ antefik tersebut patah di bagian kaki dan sebagian puncaknya berjumlah tiga.Penggambaran ragam hiasnya diawali berbentuk busur dan kemudian diakhiri dengan hiasan sulur daun yang dilengkapi dengan daun yang dilengkapi tangkai. Variasi tiga berukuran tinggi $36 \mathrm{~cm}$, lebar $35 \mathrm{~cm}$ dan tebal $20 \mathrm{~cm}$. Walaupun kondisi antefik patah yang 
memiliki 5 sudut puncak. Penggambaran ragam hiasnya diawali dengan ragam hias geometris berbentuk alokade.Sedang bagian di bagian luarnya terdapat hiasan sulur daun yang memenuhi sisi kiri dan kanan bagian antefik (Marhaeni, 2000:8).

Berdasarkan uraian di atas maka peneliti tertarik untuk meneliti permasalahan yang sudah diuraikan di atas dan penelitian ini memiliki tujuan diantaranya adalah untuk mengetahui motif flora pada candi 1,3 dan 8 pada museum candi Bumi Ayu, kedua untuk mengetahui motif flora pada candi Bumi Ayu sebagai sumber pembelajaran sejarah di sekolah menengah pertama. Dengan demikian peneliti ingin membahas dengan judul "Ragam motif flora pada candi Bumiayu sebagai sumber pembelajaran sekolah menengah pertama“.

\section{B. METODE PENELITIAN}

Metode yang digunakan dalam penelitian ini adalah metode deskriptif kualitatif. Metode deskriptif kualitatif adalah peneliti menekankan catatan dengan deskripsi kalimat yang rinci, lengkap dan mendalam yang menggambarkan situasi sebenarnya guna mendukung penyajian data (Sutopo, 2006:40).

\section{Teknik Pengumpulan Data}

Teknik pengumpulan data merupakan suatu langkah yang paling strategis dalam penelitian karena tujuan utama dalam penelitian adalah mendapatkan data ataupun sumber yang otentik. Sesuai dengan bentuk penelitian kualitatif dan juga jenis sumber data yang dimanfaatkan, maka teknik pengumpulan data yang digunakan dalam penelitian ini wawancara mendalam, observasi langsung dan dokumentasi (Sutopo,2006:228).

\section{Teknik Analisis Data}

Analisis penelitian kualitatif bersifat induktif, bahwa semua simpulan dibentuk dari semua informasi yang diperoleh dari lapangan. Proses analisis ini dilakukan bersamaan sejak awal dengan proses pengumpulan data, dengan melakukan beragam teknik refleksi bagi pendalaman dan pemantapan data. Setiap data yang diperoleh akan selalu dikomparasikan, setiap unit atau kelompoknya untuk melihat keterkaitannya sesuai dengan tujuan penelitian. Selain itu bagi pemantapan dan pendalaman data proses yang dilakukan selalu dalam bentuk siklus, sebagai usaha verifikasi (Sutopo, 2006:230).

\section{HASIL DAN PEMBAHASAN Motif Ragam Flora Di Candi Bumiayu}

Motif tumbuh-tumbuhan atau motif flora pada zaman pra-sejarah belum berkembang secara spesifik. Hal ini sesuai dengan pendapat Van der Hoop (1949) bahwa dalam zaman pra-sejarah Indonesia bahwa motif tumbuhan tidak terdapat dalam hiasan pada peralatan mereka. Tetapi pengaruh dari India yang membuat motif tumbuhan menjadi sangat umum. Sejak ini pula menjadi bagian yang utama dalam dunia ornamensi Indonesia (Sunaryo, 2009:153). Sebagaimana juga dengan ragam seni yang lain, ornament kesenian di Sumatera diperkirakan lahirnya berhubungan dengan sesuatu kepercayaan yang berkembang di masyarakat pada waktu itu. Seperti halnya kesenian lain di Nusantara seni ukir lahir dari lingkungan serta penuh dengan pesanpesan spiritual yang disampaikan dengan ukiran atau ragam hias. Sangat tipis kesadaran masyarakat akan murni hanya untuk keindahan (Marah, 1987:34).

Ragam hias hadir di tengah-tengah kehidupan masyarakat sebagai media ungkapan perasaan yang diwujudkan dalam bentuk visual, yang diproses penciptaannya tidak lepas dari pengaruh lingkungan. Rupanya di dalam bentuk ragam hias itu terdapat tedapat pula makna simbolik tertentu menurut apa yang berlaku secara konvensial dilingkungan masyarakat pendukungya.Tidak selamanya motif flora itu mengandung makna simbolik sebab sering kali gubahan-gubahan motif tumbuh- 
tumbuhan dalam ornamen Nusantara itu lebih menekankan pada segi keindahan hiasan, lebih jika tanaman-tanaman tidak teridentifikasi dengan baik, artinya tidak menggambarkan jenis tanaman atau unsur tanaman tertentu. Jenis tanaman tertentu seperti teratai yang banyak muncul pada motif hias sejak zaman Hindu dan pohon kalpataru atau pohon hayat yang memiliki makna simbolik masing-masing (Sunaryo, 2009:153).

Motif-motif hias tumbuhan diterapkan secara luas sebagai ornamen yang dipahatkan pada batu hiasan candi pada benda-benda produk mulai dari yang terbuat dari emas, perak kuningan perunggu sampai benda yang berukir dari kayu. Bentukbentuk alam yang dijadikan motif ragam hias berasal dari alam tetapi tidak diungkapkan secara realistis. Beberapa ahli berpendapat perkembangan motif flora itu berkembang secara alami dan melalui perkembangan yang panjang motif flora ini dari yang sederhana menjadi lebih berkembang dan mengutamakan aspek estetika atau keindahan (Sunaryo, 2009:153). Ada beberapa motif yang dapat dijelaskan sebagai berikut:

\section{Penyusunan Tanah Pada Candi Bumiayu}

Tanah penyusun candi Bumiayu dan lingkungannya sangat beragam dan terdiri atas beberapa macam. Hal ini sesuai dengan klasifikasi tanah yang disusun Sartohadi dalam bukunya pengantar geografi tanah. Menurutnya sistem klasifikasi tanah diperlukan untuk pengkajian tanah secara tepat di berbagai belahan bumi dan mempublikasikannya secara sistematis. Ada berbagai klasifikasi tanah yang ada di dunia tetapi hanya ada dua yang diterapkan secara luas yaitu sistem klasifikasi tanah USDA atau dikenal dengan soil taxonomy dan sistem FAO/UNESCO yang saat ini dikenal dengan WRB (Sartohadi, 2013:115).

Sistem klasifikasi ini berdasarkan pengamatan yang ada di lapangan atau observasi menurut saya ada beberapa jenis.
Pertama adalah tanah organosol atau tanah gambut berasal dari bahan induk organik biasanya dari hutan rawa atau rumput rawa. Tanah gambut mempunyai ciri-ciri dan sifat sebagai berikut: tidak terjadi differenasi sosial ketebalan lebihdari $50 \mathrm{~cm}$, warna kecoklatan tekstur debu-lempung tidak berstruktur konsistensi tidak lekat sehingga agak lengket (Sartohadi, 2013:115).

Selanjutnya adalah tanah alluvial yang dikategorikan sebagai tanah muda. Dikatakan sebagai tanah muda karena belum mengalami perkembangan lanjut dari bahan induknya. Tanah alluvial mempunyai sifat-sifat: tekstur beraneka belum terbentuk struktur. Selain itu konsistensi dalam keadaan basah lekat, $\mathrm{PH}$ adalah beraneka, kesuburan umumnya terdapat di aliran sungai dan daerah cekungan atau delta sungai ataupun terusan yang sangat cocok dengan keadaan Bumiayu yang telah saya observasi (Sartohadi, 2013:118).

Berikutnya adalah satuan tanah Regosol juga sama dikategorikan sebagai tanah muda. Hal ini karena tanah jenis ini belum menunjukan adanya perkembangan horison tanah. Tanah regosol tersusun atas bahan induk yang masih sangat sedikit mengalami alterasi dengan baik. Tanah regosol mempunyai sifat-sifat: tekstur pasir, struktur berbutir sedang dan $\mathrm{PH}$ umumnya netral. Kesuburan sedang berasal dari material induk vulkanis dan juga sungai. Peredaran tanah ini berada di daerah sekitar rawa dan aliran sungai (Sartohadi, 2013:120).

Kemudian ada juga sifat tanah podlosik merah-kuning yang ada di sekitar lingkungan candi. Tanah jenis ini merupakan lapisan yang telah berkembang. Satuan tanah ini mempunyai sifat solum tebal, tekstur lempung hingga lempung berpasir, struktur gumpal dan konsistensi lekat. Serta bersifat agak asam. Kesuburan juga rendah dan sedang, sedang warna merah hingga kuning. Satuan tanah podlosik merah-kuning berasal dari bahan induk lapukan kuarsa, bersifat asam tersebar di daerah iklim basah 
di atas $2500 \mathrm{~mm} /$ tahun (Sartohadi, 2013:120).

Terakhir adalah tanah hilosol yang terbentuk oleh bahan organic yang menysun lebih dari 50\% ketebalan tanah $80 \mathrm{~cm}$. Histolosol tidak mempunyai permafrost atau bahan gelik hingga kedalaman $100 \mathrm{~cm}$ dari permukaan tanah. Pada kategori Subordo, Histolosis diklasifikasikan atas dasar derajat kematangan bahan organiknya. Persebaran histolosis di Indonesia terutama terhadap lahan basah yaitu Sumatera, Kalimantan, Sulawesi dan Papua (Sartohadi, 2013:121).

\section{Motif Teratai}

Di antara bermacam bunga yang sering dijadikan motif hias. Sejak zaman Hindu, bunga teratai memiliki peran yang penting, yang kuntum bunganya merah disebut padma yang biru disebut utpala dan yang putih disebut kumuda. Sebagai bunga teratai memiliki ukuran yang besar padma memiliki ukuran yang lebih besar acapkali dilukiskan dalam bentuk kuncup dan bunganya menjulang di atas air. Daunnya pun ada yang bergelombang. Pada utpala bunga tidak berukuran besar serta daunnya tidak bergelombang sedangkan pada kumuda bunganya lebar mengapung di atas air, mahkotanya berbentuk runcing dan daunnya tidak bergelombang (Sunaryo, 2009:153-154).

Motif hias bunga teratai melambangkan kemurnian dan kesucian dalam kepercayaan Bhudda teratai juga merupakan simbol kemurnian karena muncul tidak tercela meskipun dari dalam lumpur. Delapan helai mahkota bunganya merupakan simbol delapan sikap kesusilaan. Di keraton Cirebon teratai dianggap sebagai lambang kebesaran dan ketataneagaran. Sejumlah patung juga dipahat pada zaman Hindu juga dilengkapi dengan bunga teratai jenis utpala dan patung Budha juga yang biasanya digambarkan berdiri atau atau duduk pada padmasagana yakni semacam singgasana dengan ornamen padma. Di zaman Islam, bunga teratai masih digubah sebagai motif hias. Motif hias bunga teratai yang diukirkan pada batu dan kayu yang dapat dijumpai pada ornamen di masjid Mantingan Jepara dan masjid kesultanan Cirebon. Di China motif bunga hias teratai banyak digunakan dan merupakan lambang lima buah tanda pengenal mengenai perwujudan, yakni pikiran perasaan, penglihatan, kebijaksanaan, dan kesadaran. Di kompleks keraton Yogyakarta terdapat pula motif hias teratai antara lain yang dipadu dengan motif hias naga dan juga tawon dan tangan bangsal stinggil. Keduanya ornamen sekaligus sengkalan memet yang menandai titimangsa berkaitan dengan pembangunan stinggil (Sunaryo, 2009:154-155).

\section{Motif Hias Patra, Lung dan Sulur}

Patra artinya daun, umumnya motif hias patra berbentuk stilisasi sehelai daun yang diulang-ulang dan tersusun berderet, tetapi patra juga dapat merupakan gubahan dedaunan yang merupakan bagian motif tumbuh-tumbuhan. Hiasan praba pada wayang kulit misalnya bagian dalamnya diisi dengan motif patra-patra dan lung. Kata lung dalam bahasa Jawa yang merujuk pada tanaman yang masih muda dan melingkar dan melengkung bentuknya. Sementara sulur dipakai menamakan motif tumbuh-tumbuhan yang digubah sebagai bentuk dasar bentuk dasar lengkung pilin tegar (Sunaryo, 2009:157).

Di Bali motif hias Patra banyak ragamnya misalnya terdapat patra satri, pattra tunggel, patra Cina dan patra tunggel. Motif patra Bali tidak hanya menggambarkan daun-daun tetapi juga bunga dan lung. Motif hias sulur yang berpola dasar pilin tegar yang sangat indah bentuknya dan merupakan stilisasi dari tumbuhan teratai. lalah yang terdapat di candi Kalasan. Di candi Prambanan terdapat ornamen bunga Pugamagala yang melukiskan tanaman sulur ikal dan bunga teratai merah dan biru yang tumbuh dari 
guci sebagai lambang kebahagiaan dan kemujuran (Sunaryo, 2009:158).

Selanjutnya motif hias sulur yang banyak diterapkan sebagai ornamendari bahan perak dan emas. Jika di Jawa umunya motif sulur bersifat luwes, lemah, gemulai dan bergerak lamban karena dibentuk diikal yang melingkar. Sebagaimana dapat ditemukan di Minangkabau dan di daerah lain seperti Madura, Kalimantan dan Batak motif sulur menyiratkan sifat luwes, dinamis gerakannya. Di Toba motif sulur sebagai lambang panjang umur sedangkan di Jawa motif sulur menggambarkan harga masa depan yang lebih baik. Beberapa motif hias ukir mendapatkan coraknya berdasarkan asal tempat berkembangnya di anataranya ialah motif hias ukir Majapahit dan lebih Bali tampak dengan unsur unsur daun pokok yang membidang dan secara keseluruhan tampil penuh. Sebaliknya motif hias ukir Jepara dan Madura lebih tampil garis (Sunaryo, 2009:159).

\section{Motif Hias Pohon Hayat}

Motif pepohonan banyak dipahatkan pada dinding candi Borobudur dan merupakan hiasan yang sangat dekoratif mengisi dan menjadi latar belakang sosoksosok tokoh yang digambarkan. Ada pohon tebu, pisang, palem atau kelapa, serta buahbuahan seperti nangka, durian, mangga dan lain-lain. Di samping itu terdapat pohon bodi atau pohon kayangan. Di candi Prambanan pohon kayangan disebut pohon kalpataru ini digambarkan berbentuk bulat, padat penuh dengan teratai biru, merah dan putih di atasnya ada burung yang bertengger dan payung (Sunaryo, 2009:160).

Sementara di sekitar pohon tepatnya di bawah kiri dan kana nada kinara dan kinari mahluk dari kayangan yang bentuknya setengah manusia dan setengah burung. Pohon kalpataru ini mengapit motif singa dan merupakan motif khas Prambanan. Menurut Soekmono pohon kalpataru merupakan pohon yang dapat mengabulkan semua keinginan manusia. Di candi Jawa Timur motif pohon yang berbentuk segitiga berperan sebagai "pembatas" penggambaran adegan reliefnya (Sunaryo, 2009:161).

Gunungan dalam wayang sesungguhnya merupakan penggambaran makrokosmos yang di dalamnya terdapat pohon hayat. Gunungan atau hardi tidak saja berarti gunung, melainkan pohon hayat, pohon kehidupan karena itu disebut pula kekayon yang berarti kekayuan atau keinginan. Pohon hayat merupakan pohon keramat yang menyatukan dunia atas dan dunia bawah. la merupakan lambang keesaan tertinggi dan keutuhan. Selanjutnya pohon hayat merupakan sumber hidup kekayaan, dan kemakmuran. Meskipun dalam bentuk yang berbeda-beda motif hias pohon hayat tersebut tersebar di berbagai wilayah tanah air. Di Batak, Kalimantan Utara, Sumatera Utara, Sumatera Selatan, Jawa, Bali dan Nusa Tenggara Timur (Sunaryo, 2009:163).

Di Jawa dan Bali motif pohon ini dalam pertunjukan wayang disebut kayon atau gunungan. Bentuk kayon atau gunungan di Jawa yang dikembangkan pada periode Islam, keseluruhannya berbentuk segitiga meruncing ke atas dengan sedikit lengkungan di bagian bawah sehingga terdapat bagian yang menyembul dan lekuk yang disebut ganukan dan lengkeh. Bentuknya yang menjulang seperti gunung itu dinamakan gunungan. Gunung merupakan tempat keramat sebagai tempat roh atau dewa. Nama kayon terkait dengan kata kayu yang dalam bahsa Jawa berarti pohon yang dapat menjawab semua keinginan (Sunaryo, 2009:171).

\section{Fragmen Hiasan Motif lkal}

Fragmen yang ada di candi Bumiayu telah lama dilupakan orang. Kebetulan ada seseorang yang memberitahukannya kepada kami, sehingga Kami dapat melihat fragmen itu. Fragmen itu ternyata sejak lama digunakan sebagai pijakan dan tidak 
diperdulikan orang. Letaknya terbalik dan hanya segitiga itu muncul dari dalam tanah. Walaupun begitu fragmen itu masih dibiarkan di tempat semula. Batu itu digali ternyata di situ selain ada motif teratai juga ada motif ikal beserta hewan (Sunaryo, 2009:174).

Tampaknya itu adalah padmasana yang merupakan kepercayaan Hindu. Unsur terbawah adalah hiasan bunga teratai yang kiranya merupakan padmasana. (Separo bawahnya agaknya terdapat pada fragmen di bawahnya yang telah lama hilang). Setelah itu di sisi kiri teratai ada motif ikal di sisi kiri dan kanan dan juga ada empat kepala singa yang menggigit padma. Dan untaian ratna yang menggantung membentuk setengah lingkaran dari mulut ke-mulut. Unsur tengahnya polos unsur teratas dengan ukiran kepala lagi dengan mata memandang ke bawah. Di atasnya terdapat ukiran yang merupakan hiasan teratas fragmen ini berupa ornamen kelung kelok mendatar dan keliling. Tinggi fragmen ini $60 \mathrm{~cm}$, garis tengah $23 \mathrm{~cm}$ sedangkan garis bawah $20 \mathrm{~cm}$ (Sunaryo, 2009:174).

\section{Ragam Hias di Candi Bumiayu}

Ragam hias bonggol pada antefik dari candi Bumiayu 3, bervariasi walau pada dasarnya berupa Sulur. Adapun variasi ragam hias bonggol sebagai berikut:

\section{Variasi 1}

Antefik ragam hias bonggol variasi 1 dipahatkan pada antefik berpuncak tiga dengan ukuran tinggi $22 \mathrm{~cm}$ lebar $16 \mathrm{~cm}$ dan tebal $14 \mathrm{~cm}$. Penggambaran ragam hias ini didominasi oleh sulur daun. Rangkaian hiasannya ditempatkan secara berurutan dari bawah ke atas, yaitu diawali ragam hias bonggol yang menyerupai vas bunga dan kemudian diakhiri dengan hiasan sulur daun bercabang 2 yang menjalar sehingga memenuhi bagian atas dan samping bagian atas samping bidang atasnya (Marhaeni, 2000:6).

\section{Variasi 2}

Variasi hiasan flora yang
memperlihatkan ragam hias bonggol terdapat pula pada sebuah antefik berpuncak 5 dengan ukuran tinggi $17 \mathrm{~cm}$, lebar $16 \mathrm{~cm}$, tebal $7 \mathrm{~cm}$. Ragam hiasnya bonggol variasi 2 ini berupa bonggol yang menyerupai guci serta hiasan sulur daun yang memenuhi bagian atas dan samping kiri kanan bidang pahatan antefik (Marhaeni, 2000:7).

\section{Variasi 3}

Ragam hias bonggol variasi 3 dipahatkan pada sebuah antefik sudut dengan ukuran tinggi $18 \mathrm{~cm}$, lebar $16,5 \mathrm{~cm}$, tebal $20 \mathrm{~cm}$. Antefik tersebut berpuncak 5 . Ragam hiasnya berbentuk bonggol yang bagian dalamnya diberi hiasan berbentuk lingkaran konsentris yang terputus yang mungkin dimaksudkan sebagai stilasian akar. Dari bonggol keluar tangkai dan kemudian diakhiri dengan hiasan sulur-sulur daun yang memenuhi bagian samping kanan-kiri bidang pahatan (Marhaeni, 2000:7).

\section{Variasi 4}

Ragam hias bonggol variasi 4 ditemukan pada sebuah antefik berpuncak 3 dengan ukuran tinggi $26 \mathrm{~cm}$, lebar $18 \mathrm{~cm}$, tebal $14,5 \mathrm{~cm}$. Antefik ini utuh. Ragam hias variasi 4 berbentuk bonggol yang mempunyai vas bunga dengan cekungan berbentuk lingkaran. Dari bagian atas bonggol mencuat tangkai dan sulur daun yang memenuhi bagian atas tepian antefik. Pengamatan tekhnik menunjukan ragam hias bonggol dengan empat variasinya yang dipahatkan pada tiang antefik tersebut dimasukan berbentuk lingkaran (Marhaeni, 2000:8).

\section{Ragam Hias Sulur Pada Antefik}

Jenis-jenis hiasan sulur dapat dibedakan atas beberapa variasi sebagai berikut: 


\section{Variasi 1}

Ukuran antefik berhias variasi 1 adalah tinggi $16 \mathrm{~cm}$, lebar $10 \mathrm{~cm}$, dan tebal $20 \mathrm{~cm}$. Antefik tersebut berpuncak 5. Ragam hiasnya berbentuk sulur daun yang memenuhi bagian tepian bidang antefik. Di bagian tengah bidang pahatannya terdapat hiasan berbentuk stasilan figur manusia berdiri kangkang. Ragam hiasnya tersebut dipahatkan dengan kedalaman 2-3 cm (Marhaeni, 2000:9).

\section{Variasi 2}

Antefik berhias variasi 2 berukuran tinggi $31 \mathrm{~cm}$, lebar $25 \mathrm{~cm}$ dan tebal $9 \mathrm{~cm}$. Antefik tersebut patah pada bagian kaki dan sebagian puncaknya yang berjumlah 3 . Penggambaran ragam hiasnya diawali dengan hiasan berbentuk busur dan kemudian diakhiri dengan hiasan sulur daun yang dilengkapi dengan tangkai yang memenuhi bagian atas bidang pahatan antefik.

\section{Variasi 3}

Antefik beragam hias sulur variasi 3 berukuran tinggi $36 \mathrm{~cm}$, lebar $35 \mathrm{~cm}$, dan tebal $20 \mathrm{~cm}$. Walaupun kondisi patah di bagian atasnya namun masih dapat diidentifikasi memiliki 5 sudut puncak. Penggambaran ragam hiasnya diawali dengan ragam hias geometris berbentuk alokade. Sedang di bagian luarnya terdapat hiasan sulur daun yang memenuhi bagian sisi kanan-kiri bagian pahatan antefik kedalaman pahatannya kurang lebih 3-4 cm (Marhaeni, 2000:8).

\section{Ragam Hias Sulur dan Bunga Pada Panil}

Pada beberapa buah bata yang diperkirakan sebagai panil terdapat ragam hias tumbuhan (flora) berupa ragam hias sulur daun yang dipadukan dengan ragam hias bunga. Di antara sekian variasinya dapat dipaparkan sebagai berikut:

\section{Variasi 1}

Ragam hias sulur dan bunga variasi 1 ditemukan pada panil persegi panjang berukuran tinggi $30 \mathrm{~cm}$, lebar $40 \mathrm{~cm}$ dan tebal $20 \mathrm{~cm}$. Panil tersebut patah di bagian sudut kiri bawah. Penggambaran ragam hiasnya diawali dengan bentuk ceplok bunga berkelopak empat pada sisi kanan dan permata pada sisi kiri. Kemudian diakhiri dengan bentuk sulur yang disusun berjajar memenuhi bagian atas bidang hias (Marhaeni, 2000:8).

\section{Variasi 2}

Ragam hias sulur dan bunga variasi 2 terdapat panil empat persegi panjang berukuran tinggi $30 \mathrm{~cm}$, lebar $60 \mathrm{~cm}$ dan tebal $20 \mathrm{~cm}$. Panil tersebut mempunyai sudut siku-siku di bagian tengahnya. Ragam hiasnya berbentuk bonggol yang dari bagian atasnya mencuat tangkai ke atas dan samping dan ke samping kanan-kiri serta kemudian diakhiri dengan hiasan sulur daun yang memenuhi bidang kiri-kanan tepian panil. Ragam hias tersebut dipadukan dengan ragam hias geometris berupa lengkung (Marhaeni, 2000:9).

\section{Variasi 3}

Ragam hias sulur daun dan bunga variasi 3 digambarka pada panil persegi panjang berukuran tinggi $24 \mathrm{~cm}$, lebar $40 \mathrm{~cm}$ dan tebal $20 \mathrm{~cm}$. Ragam hiasnya berpusat pada sekuntum bunga berkelopak enam dengan putik yang digambarkan dengan goresan-goresan. Di sekitar kelopak bunga diberi stilasian daun. Sekuntum bunga Sekuntum bunga tersebut seolah-olah berada di dalam busur yang dibentuk dari rangkaian daun. Pengamatan tekhnik pemahatan menunjukan ragam hias sulur dan bunga variasi 1,2,3 yang dipahatkan pada beberapa panil tersebut rata-rata kedalaman 3-6 cm. Dengan demikian dapat dimasukan ke dalam kategori relief sedang. Penggarapan permukaan terkesan halus. Penggambaran naturalis dan luwes. Panil seperti itu biasanya diletakan menempel pada bagian tubuh bangunan candi (Marhaeni, 2000:9). 


\section{Motif Pucuk Rebung}

Ragam hias motif jenis ini adalah motif tradisional Sumatera Selatan. Motif ini adalah motif matahari yang biasanya terdapat pada dinding maupun pintu. Pada bagian lingkar luarnya terdapat motif tumpal (pucuk rebung) yang bagian runcingnya menghadap ke dalam tanpa isian atau polos. Bagian dalam merupakan bubujalan atau pusar. Pada bagian paling tengah terdapat lubang yang berfungsi sebagai ventilasi yang juga untuk melihat dari dalam apabila ada orang yang mengetuk pintu (Marhaeni, 2000:10).

Ukiran lain motif rebung dengan motif bunga matahari pada bagian tengah. Bagian sampingnya terdapat bunga-bunga atau daun yang melingkar. Pada bagian tengah terdapat bunga-bunga yang tersusun rapi. Dengan lubang yang ada di tengahnya (Marhaeni, 2000:10).

\section{Pembahasan}

Berdasarkan hasil observasi dan wawancara di SMP Sriguna Palembang. Peneliti mengetahui bahwa sekolah ini menggunakan kurikulum lama yaitu KTSP 2006 sesuai dengan ketetapan pemerintah. Pada silabus pembelajaran sejarah kelas VII pada standard kompetensi 5. memahami perkembangan masyarakat sejak masa Hindu-Bhudda sampai pada masa kolonial Eropa. Sedangkan untuk kompetensi dasar 5.1 mendeskripsikan kehidupan masyarakat kebudayaan serta pemerintahan dan peninggalannya-peninggalannya. Serta materi pokok peninggalan sejarah masa Hindu-Budha. Walaupun tidak dibahas secara jelas tentang motif ragam flora pada candi Bumiayu, materi ini dapat dimasukan dalam silabus melalui materi peninggalan sejarah kerajaan masa Hindu-Budha yang dapat dijadikan materi sejarah lokal.

Ragam motif flora pada candi Bumiayu ada beberapa motif flora. Pertama adalah motif teratai. bunga ini sering dijadikan motif hias. Sejak zaman Hindu. Bunga teratai memiliki peran yang penting, yang kuntum bunganya merah disebut padma yang biru disebut utpala dan yang putih disebut kumuda. Sebagai bunga teratai memiliki ukuran yang besar padma memiliki ukuran yang lebih besar acapkali dilukiskan dalam bentuk kuncup dan bunganya menjulang di atas air. Daunnya pun ada yang bergelombang. Pada utpala bunga tidak berukuran besar serta daunnya tidak bergelombang sedangkan pada kumuda bunganya lebar mengapung di atas air, mahkotanya berbentuk runcing dan daunnya tidak bergelombang.

Motif hias bunga teratai melambangkan kemurnian dan kesucian dalam kepercayaan Budha teratai juga merupakan simbol kemurnian karena muncul tidak tercela meskipun dari dalam lumpur. Delapan helai mahkota bunganya merupakan simbol delapan sikap kesusilaan. Di keraton Cirebon teratai dianggap sebagai lambang kebesaran dan ketataneagaran. Sejumlah patung juga dipahat pada zaman Hindu juga dilengkapi dengan bunga teratai jenis utpala dan patung Budha juga yang biasanya digambarkan berdiri atau atau duduk pada padmasagana yakni semacam singgasana dengan ornamen padma. Di zaman Islam, bunga teratai masih digubah sebagai motif hias. Motif hias bunga teratai yang diukirkan pada batu dan kayu yang dapat dijumpai pada ornamen di masjid Matingan Jepara dan masjid Kesultanan Cirebon. Di China motif bunga hias teratai banyak digunakan dan merupakan lambang lima buah tanda pengenal mengenai perwujudan, yakni pikiran perasaan, penglihatan, kebijaksanaan, dan kesadaran. Di kompleks keraton Yogyakarta terdapat pula motif hias teratai antara lain yang dipadu dengan motif hias naga dan juga tawon dan tangan bangsal stinggil. Keduanya ornamen sekaligus sengkalan memet yang menandai titimangsa berkaitan dengan pembangunan stinggil.

Kedua adalah motif tumbuhan paku. Kaluak paku merupakan kata-kata adat 
yang sangat populer di Sumatera terutama Minangkabau. Bunyinya sebagai berikut:

Kaluak paku kacang balimbiang

Tampuruang lenggang-lenggangkan

Baok manurun ka saruaso

Tanam siriah jo eruknyo

Anak dipangku kamanakan dibimbiang

Tenggang nagari jangan binasa

Tenggang sarato jo adatnyo

Demikian pepatah adat yang melambangkan aturan hidup masyarakat yang baik. Adat ini mengajarkan seseorang janganlah hanya memikirkan kepentingan anaknya saja. la juga harus membimbing kemenakannya tidak boleh lupa pada tetangga dan negerinya. Hidup tidak boleh mementingkan diri sendiri ingatlah juga kepentingan orang lain. Ragam hias "kaluak paku" melambangkan budi pekerti yang baik yang harus dimiliki oleh setiap anggota masyarakat. Gelung ujung pakis yang belum mekar sebagai motif karena keindahan dan kegemulaian bentuk ujung daun itu. Motif ini banyak mengambil bentuk gelung yang ritmis seakan membentuk spiral. Ukiran ini banyak dipakai pada tonggak atau tiang rumah adat.

Motif pohon hayat atau pohon kalpataru yang merupakan motif pohon kehidupan dalam mitologi Hindu. Di candi Prambanan pohon kayangan disebut pohon kalpataru ini digambarkan berbentuk bulat, padat penuh dengan teratai biru, merah dan putih di atasnya ada burung yang bertengger dan payung.Sementara di sekitar pohon tepatnya di bawah kiri dan kana nada kinara dan kinari mahluk dari kayangan yang bentuknya setengah manusia dan setengah burung. Pohon kalpataru ini mengapit motif singa dan merupakan motif khas Prambanan. Menurut Soekmono pohon kalpataru merupakan pohon yang dapat mengabulkan semua keinginan manusia. Di candi Jawa Timur motif pohon yang berbentuk segitiga berperan sebagai "pembatas" penggambaran adegan reliefnya.
Gunungan dalam wayang sesungguhnya merupakan penggambaran makrokosmos yang di dalamnya terdapat pohon hayat. Gunungan atau hardi tidak saja berarti gunung, melainkan pohon hayat, pohon kehidupan karena itu disebut pula kekayon yang berarti kekayuan atau keinginan. Pohon hayat merupakan pohon keramat yang menyatukan dunia atas dan dunia bawah. la merupakan lambang keesaan tertinggi dan keutuhan. Selanjutnya pohon hayat merupakan sumber hidup, kekayaan, dan kemakmuran. Meskipun dalam bentuk yang berbeda-beda motif hias pohon hayat tersebut tersebar di berbagai wilayah tanah air. Di Batak, Kalimantan Utara, Sumatera Utara, Sumatera Selatan, Jawa, Bali dan Nusa Tenggara Timur.

Motif pohon hayat di daerah Batak disebut gorga mariara sundung di langit. Motif hias ini berbentuk pohon seperti cemara tapi dahannya membentuk pola lengkung dan ikal. Sementara di bagian atas terdapat burung baik yang bertengger $\mathrm{di}$ atas dahan maupun maupun yang diletakan di atas pohon. Di bawah akar pohon tampak kuat memancar dan batang pohon dililit ular. Menurut Eko Prawato motif hias pohon hayat masyarakat Batak ini menceritakan sejarah. Gambar burung di sebelah atas yang disebut manuk-manuk hambalajati berwarna putih yang membawa berkah.

Pada kain Kroe di Sumatera Selatan terdapat tenun yang diberi pohon hayat sebagai pohon keramat yang ditanam di tengah-tengah desa atau panggung. Di atas panggung itu digambarkan orang-orang berjajar memegang tombak dan paying, mungkin sekali sebagai penggambaran nenek moyang. Di samping itu di bagian tepi atau sudut terdapat motif tanduk kerbau. Bentuk pohon yang digambarkan tegak menjulang tinggi dengan dahan-dahan panjang ke-arah atas yang ujungnya ikal dan berkait pola geometris. Sementara bagian rantingnya dihiasi daun-daun yang menggantung. Di sekililing pohon itu terdapat burung-burung yang dapat 
dikaitkan dengan penggambaran dari para roh.

Motif pohon hayat pada suku Dayak Kalimantan yang disebut batang garing sering kali digunakan untuk menghias anyaman tikar. Sebagai motif pohon hayat batang garing juga memiliki pola yang menarik berupa pola geometri. Pohon ini berbentuk tombak dan menunjuk ke atas. Menurut Teras Mihing pohon ini melambangkan Ranying Mahatala langit penguasa dunia atas. Di bagian bawah terdapat guci berisi air suci melambangkan Jata atau Tambun penguasa dunia bawah. Dengan ini disampaikan bahwa dunia atas dan bawah bukan lah dunia berbeda tapi pada hakekatnya adalah satu.

Dahan-dahan dan ranting digambarkan menyebar ke berbagai arah dan berbentuk lekuk berkait sedemikian rupa sebagai lambang Jata sedangkan daun-daunnya berbentuk ekor enggang dan demikian melambangkan kesatuan. Pohon batang garing bertumpu pulau Batu Nindan Tarung sebagai tempat kediaman manusia pertama sebelum manusia diturunkan ke bumi. Di bagian puncak terdapat burung enggang sebagai lambang Ranying Mahatala Langit sebagai sumber segala kehidupan. Selain bentuk motifnya yang indah, pohon ini menggambarkan falsafah hidup orang Dayak Kalimantan.

Di Jawa dan Bali motif pohon ini dalam pertunjukan wayang disebut kayon atau gunungan. Bentuk kayon atau gunungan di Jawa yang dikembangkan pada periode Islam, keseluruhannya berbentuk segitiga meruncing ke atas dengan sedikit lengkungan di bagian bawah sehingga terdapat bagian yang menyembul dan lekuk yang disebut ganukan dan lengkeh. Bentuknya yang menjulang seperti gunung itu dinamakan gunungan. Gunung merupakan tempat keramat sebagai tempat roh atau dewa. Nama kayon terkait dengan kata kayu yang dalam bahsa Jawa berarti pohon yang dapat menjawab semua keinginan.
Sebagai pohon hayat gunungan melambangkan keutuhan dan keesaan.la juga menggambarkan kosmos. Alam semesta ini penuh dengan dua unsur yang saling bertentangan seperti gelap dan terang, laki dan perempuan dunia atas dan bawah. Keduanya saling melengkapi dan menyempurnakan dan diharmoniskan dengan pohon kehidupan sebagai poros kosmos. Ada dua tipe gunungan wayang gunungan wadon (perempuan) dan gunungan lanang (laki-laki).

Batik motif pohon hayat digambarkan lebih sederhana tetapi bervariasi artinya bentuknya merupakan stilisasi tumbuhan yang umumnya dipadukan dengan motifmotif lain pada motif batik tertentu. Kadang motif pohon ini itu tampak lengkap dengan unsur akar, batang, daun dan bunga pada motif senen rama. Dalam tenun ikat Sumba motif pohon hayat ini dengan garis ikal dengan garis ikal semakin mengecil di atas. Di saping itu terdapat motif yang khas yaitu motif tengkorak pada kain motif Sumba Timur. Pohon tengkorak yang terdapat hinggi nomu kain yang digambarkan dipakai oleh para laki-laki dan bangsawan. Banyak lagi motif yang dapat dijelaskan tetapi tidak dapat dijelaskan satu persatu.

Kelas VII berjumlah 7 kelas yaitu kelas 7.1 sampai dengan 7.7. Kemudian peneliti melakukan observasi tentang kekuarangan dan kelebihan sumber pembelajaran yang ada di kelas VII serta mencocokkan layak atau tidaknya materi peneliti dimasukkan dalam pembelajaran yaitu Motif flora pada Candi Bumiayu Sebagai Sumber Pembelajaran Sejarah Sekolah Menengah Pertama Sriguna Palembang.

Sebelum mengadakan penelitian menyiapkan bahan ajar dan RPP sesuai bahan ajar yang ingin diteliti. RPP dan bahan ajar itu dikonsultasikan pada guru mata pelajaran IPS Terpadu kelas VII yaitu Munyati S.Pd. guna mengetahui kelayakan materi ini. Setelah diketahui bahwa materi ini layak maka bahan ajar ini dapat digunakan oleh guru tersebut untuk 
mengajarkannya pada kelas VII tahun berikutnya. Berdasarkan hasil penelitian yang dilakukan di SMP Sriguna Palembang tentang Motif Ragam Flora pada Candi Bumiayu Sebagai Sumber Pembelajaran Sejarah Sekolah Menengah Pertama Sriguna Palembang dapat dijadikan sumber pembelajaran tambahan yang dapat dijadikan wawasan pengetahuan sejarah lokal yang banyak kurang diketahui oleh siswa karena kurangya sumber pembelajaran sejarah lokal.

\section{SIMPULAN}

Motif itu antara lain adalah bunga teratai, bunga pucuk rebung, motif patra, daun dan lung, motif ikal. Pertama adalah bunga teratai. Sejak zaman Hindu, bunga teratai memiliki peran yang penting.Kuntum bunganya merah disebut padma yang biru disebut utpala dan yang putih disebut kumuda. Padma memiliki ukuran yang lebih besar acapkali dilukiskan dalam bentuk kuncup dan bunganya menjulang di atas air. Daunnya pun ada yang bergelombang. Pada utpala bunga tidak berukuran besar serta daunnya tidak bergelombang sedangkan pada kumuda bunganya lebar mengapung di atas air, mahkotanya berbentuk runcing dan daunnya tidak bergelombang. Motif hias bunga teratai melambangkan kemurnian dan kesucian, dalam kepercayaan Budha teratai merupakan simbol kemurnian karena muncul tidak tercela meskipun dari dalam lumpur. Delapan helai mahkota bunganya merupakan simbol delapan sikap kesusilaan. Di keraton Cirebon teratai dianggap sebagai lambang kebesaran dan ketataneagaran. Sejumlah patung juga dipahat pada zaman Hindu juga dilengkapi dengan bunga teratai jenis utpala dan patung Budha juga yang biasanya digambarkan berdiri atau atau duduk pada padmasa yakni semacam singgasana dengan ornamen padma.

Kedua adalah motif patra. Patra artinya daun, umumnya motif hias patra berbentuk stilisasi sehelai daun yang diulang-ulang dan tersusun berderet, tetapi patra juga dapat merupakan gabungan dedaunan yang merupakan bagian motif tumbuh-tumbuhan. Hiasan praba pada wayang kulit misalnya bagian dalamnya diisi dengan motif patrapatra dan lung. Kata lung dalam bahasa Jawa yang merujuk pada tanaman yang masih muda dan melingkar dan melengkung bentuknya. Sementara sulur dipakai menamakan motif tumbuh-tumbuhan yang diubah sebagai bentuk dasar bentuk dasar lengkung pilin tegar.

\section{DAFTAR PUSTAKA}

Dimyati dan Mudjiono. 2010. Belajar dan Pembelajaran. Jakarta: Rinneka Cipta.

Marhaeni, Tri DKK. 2000. Analisis Candi Bumiayu 3 Kabupaten Muara Enim Provinsi Sumatera Selatan. Palembang: Balai Arkeologi.

Marah, Risman. 1988. Ragam Hias Minangkabau. Jakarta: Departemen Pendidikan dan Kebudayaan.

Munandar. 2007. Peradaban Sungai Lematang. Palembang: Balai Arkeologi. Novita, Aryandini. 2011. Asia Tenggara Dalam Perspektif Arkeologi. Palembang: Balai Arkeologi Palembang.

Sunaryo, Aryo. 2009. Ornamen Nusantara. Semarang: Dahara Prize.

Sitepu, B.P. 2014. Pengembangan Sumber Belajar. Jakarta: Raja Grafindo Persada.

Sugara, Robi. 2015. Nilai Budaya Candi Bumiayu Sebagai Materi Pengayaan Pembelajaran Sejarah Di Kelas VII SMP Negeri 2 Tanah Abang. Palembang: Universitas PGRI Palembang (Tidak Diterbitkan).

Sutopo, H.B. 2006. Metodologi Dasar Teori dan Terapannya dalam Penelitian. Surakarta: Universitas Sebelas Maret.

Toekio, Soegeng, M. 2004. Ragam Hias Indonesia. Bandung: PT Angkasa. 
